Volume 13

Issue 3 Critical Genocide and Atrocity

Prevention Studies

$12-20-2019$

\title{
Human Rights? What a Good Idea! From Universal Jurisdiction to Crime Prevention
}

Daniel Feierstein

Universidad Tres de Febrero, Buenos Aires / CONICET / Universidad de Buenos Aires

Follow this and additional works at: https://digitalcommons.usf.edu/gsp

\section{Recommended Citation}

Feierstein, Daniel (2019) "Human Rights? What a Good Idea! From Universal Jurisdiction to Crime Prevention," Genocide Studies and Prevention: An International Journal: Vol. 13: Iss. 3: 9-20.

DOI:

https://doi.org/10.5038/1911-9933.13.3.1669

Available at: https://digitalcommons.usf.edu/gsp/vol13/iss3/4

This Articles is brought to you for free and open access by the Open Access Journals at Digital Commons @ University of South Florida. It has been accepted for inclusion in Genocide Studies and Prevention: An International Journal by an authorized editor of Digital Commons @ University of South Florida. For more information, please contact digitalcommons@usf.edu. 


\title{
Human Rights? What a Good Idea! From Universal Jurisdiction to Crime Prevention
}

\author{
Daniel Feierstein \\ Universidad de Buenos Aires \\ Buenos Aires, Argentina
}

One of humanity's greatest achievements in the last century has been the creation of international courts of law to judge those responsible for state crimes such as genocide. These courts were originally a response to the wholesale destruction of European societies by the Nazis during World War II. The human rights conventions which proliferated in the post-war period attempted to create an effective universal jurisdiction to limit the punitive power of the state, especially where large numbers of the civilian population were involved.

The doctrine of universal jurisdiction grew out of the realization that certain state crimes destroyed the social fabric to such an extent that they were unlikely to be prosecuted in the territory where they had been committed. The only way of bringing the perpetrators to justice would be to start legal proceedings in international or regional courts or in the national courts of other countries. This, of course, was no easy task, but universal jurisdiction offered new hope to the victims of genocide and massacres by establishing that such crimes were no longer subject to amnesties or statutes of limitations.

The Nuremberg and Tokyo War Crimes Trials (1945-1948) were highly problematic and raised numerous valid questions. Only the defeated powers were put on trial and they were tried by military tribunals made up of judges from the nations that had won the Second World War. It was said that this was "Victor's Justice" and that due process and several of the procedural rights of the accused were not respected. ${ }^{1}$ However, it spelt the end of impunity for at least some Nazi and Japanese leaders. It also encouraged oppressed peoples to demand justice for state crimes they had suffered and to persist in their demands for years to come.

Nevertheless, universal jurisdiction has been subject to different interpretations, depending on the role of international and regional institutions in the fight against impunity. Examples of conflicting interpretations are found in the rulings of the ad hoc International Criminal Tribunals on the Former Yugoslavia and Rwanda, and Mixed Tribunals in the cases of East Timor, Cambodia and Sierra Leone. They are also found in the rulings of national courts (paradoxically less visible) in important cases like Bosnia-Herzegovina, Argentina, Chile, Bangladesh, Colombia, Mexico and Uruguay, among other countries.

More disturbingly, the different attempts to prosecute and punish state crimes in International Tribunals have gradually evolved into a self-referential system that tends to invalidate or ignore national courts in favor of a new international criminal justice approach. Instead of complementing the work of national courts, these new international institutions have gradually transformed themselves into the main instruments for prosecuting human rights violations. This has happened despite their frequent ignorance of the history, language and culture of the countries concerned.

The result is an inefficient and self-perpetuating bureaucracy that has significantly altered the original intention behind universal jurisdiction. This inefficiency can be seen clearly in the International Criminal Court, which has only managed to convict two people in 16 years. The ICC is also criticized for focusing on African countries and not intervening in other important cases (e.g. Afghanistan, Colombia, Honduras, Iraq, Mexico, among many others).

However, the inefficiency of the ICC is less dangerous than the discourse of prevention that has developed parallel to it. Since the end of the Cold War, the concept of universal jurisdiction has shifted from prosecuting State crimes, which would otherwise go unpunished, to military intervention to "prevent" crimes before they are committed. The worst example was the United Nations attack on Libya in 2011 in response to reports of "possible" crimes against humanity attacks for which the UN invoked the new international principle of "responsibility to protect" (R2P), approved in 2005. In fact, the attacks plunged Libya into anarchy, producing many more deaths than they were intended to prevent. Unfortunately, the clamor for "intervention" comes

${ }^{1}$ See, for example, Luis Jiménez de Asúa, Tratado de Derecho penal, Tomo II (Buenos Aires: Editorial Losada, 1950). Also,

Danilo Zolo, La justicia de los vencedores. De Nuremberg a Bagdad (Buenos Aires: Edhasa, 2007). 
not only from diplomats, politicians and the mass media but - more alarmingly - from many genocide and human rights scholars and activists.

This paper critically evaluates the use of international laws designed to punish genocide, war crimes and crimes against humanity as legitimations for military intervention to prevent disasters that have not yet occurred. In other words, it deals with the thorny issue of atrocity prevention. It argues that the legitimation of "pre-emptive" killing, far from defending human rights, has become yet another way to violate them. Indeed, the "responsibility to protect" is being used to ensure control of oil and gas resources and geopolitical enclaves where previous discourses (e.g. the Cold War and the War on Terror) have lost their efficacy. It contrasts levels of violence in hotspots around the world with calls to protect civilian populations, and shows that intervention does not reduce violence and often achieves the opposite effect.

\section{Core Elements of the New Principle of Responsibility to Protect (R2P)}

The principle of "responsibility to protect" emerged from an international conference on issues of national sovereignty and the possibility of intervention. The International Commission on Intervention and State Sovereignty (ICISS) met in September 2000 and produced its final report in 2001 with the title "The Responsibility to Protect". The report analyzed three obligations: the responsibility to react, to prevent and to rebuild. But the fundamental issue, made clear through the name of the Commission itself, was the possibility of international "intervention" in cases of systematic human rights violations. The justification for suspending state sovereignty in such cases was the failure of the international community to prevent genocide in the former Yugoslavia (19921995) and Rwanda (1994). ${ }^{2}$

From then onward, the principle of Responsibility to Protect (R2P) became the focus of dozens of organizations and think tanks, such as the Coalition for the Responsibility to Protect, the Global Center for R2P, the Asia-Pacific Center for R2P or the Canadian Center for the Responsibility to Protect. It is worth to point out that many of these organizations are subsidized by the American Department of State, the Australian and Canadian governments, or the foundations of private companies with interests in intervention or subsequent "reconstruction" in overseas countries.

Soon after the report appeared, the principle was adopted unanimously by the United Nations General Assembly in September 2005. Three years later, in 2008, the General Secretary appointed a UN Special Adviser on Responsibility to Protect. Thanks to agreements, diplomatic pressure or an inability to foresee the consequences, the principle of R2P was still supported - or at least not opposed - by the majority of UN member states in 2015. It is true that there has been occasional dissent, such as the Brazilian government's criticism of intervention in Libya and its proposal to establish a "Responsibility while Protecting" (in view of the damage produced by the intervention forces themselves). However, only a handful of States have regularly protested, including - most significantly - Belarus, Cuba, India, Russia, Sudan, Syria and Venezuela.

The 2005 UN document transformed the original principles (prevent, react and rebuild) into three pillars. Pillar I affirms that States carry the primary responsibility to protect their populations (whether nationals or not) from genocide, war crimes, crimes against humanity, and ethnic cleansing; Pillar II says that the international community (including the UN, regional organizations, governments, and civil society) is committed to helping States acquire the capacity to fulfill their primary responsibility of protecting their population from mass atrocities; Pillar III follows with the commitment that, when a State is manifestly failing to protect its population from mass atrocities, or is perpetrating the atrocities itself, then the international community must take timely and decisive action to prevent and halt genocide, war crimes, crimes against humanity, and ethnic cleansing.

With one or two exceptions, such as the intervention in Kenya between 2008 and 2013, the reality, however, is that the first and second pillars have not been implemented. ${ }^{3}$ Instead, the

\footnotetext{
${ }^{2}$ For the origin of the principle of "responsibility to protect" see James Waller, Confronting Evil. Engaging our Responsibility to Prevent Genocide (New York: Oxford University Press, 2016).

${ }^{3}$ See the report of the International Coalition for the Responsibility to Protect, "Crisis in Kenya," accessed September 22, 2019, www.responsibilitytoprotect.org/index.php/crises/crisis-in-kenya for the peacekeeping intervention in
} 
regulatory authority's main aim has been to suspend national sovereignty and the prohibition against the use of force in cases where "atrocity crimes" are being (or are likely to be) committed. This being so, it is necessary to establish who determines the seriousness of such crimes - or the potential seriousness of possible future crimes - in different parts of the world. Above all, it is necessary to check whether justifications for R2P are, in fact, borne out in practice.

\section{Critical Analysis of Military Intervention (the Last Resort of R2P)}

The two main criteria for military intervention under the responsibility to protect (Pillar 3) are:

1) Military Intervention is necessary in societies with a high risk of violent death among civilians; and

2) Military intervention is necessary to reduce levels of violence against civilians.

These are the only justifications for violating State Sovereignty.

To decide whether these criteria have been met, the first step is to identify those conflicts with the largest numbers of victims and the highest civilian casualty ratios. Obviously, numbers can never explain the whole picture. Numbers have to be interpreted. Moreover, even when estimates are based on reliable sources, these figures are still estimates. We normally speak of a range of estimates rather than a fixed and precise number. However, with these provisos in mind, the different estimates give us at least a starting point from which to interpret the data.

The preliminary data presented in this paper shows an astonishing mismatch between the countries in which the R2P principle has been applied through military intervention and the most violent countries in terms of civilian casualties. Figure 1 shows the ten most important conflicts in terms of number of casualties during the last 10 years and Figure 2 shows the first ten conflicts in terms of civilian casualty ratios. What is clear from both is that some countries are clearly excluded from the R2P discourse. This may be due to lack of interest among the self-appointed protectors or to their alliances with the perpetrators. That is very clear in Sri Lanka (5th in number of casualties and 2nd in civilian casualty ratios), Pakistan (4th in number of casualties) or Israel (10th in civilian casualty ratios) - although Israel is at least present in the media. Finally, we should not forget Yemen, which has received very little attention despite the number of victims (7th in number of casualties and 8th in civilian casualty ratios).

The second step in deciding whether interventions have been justified is to see whether they have reduced levels of violence against civilians. In fact, what we find in those cases present in UN or mass media discourses is that most deaths occurred after the military intervention. This was so in Syria, Afghanistan, Iraq and Libya, for example. Figure 1 and Figure 2 show civilian casualties before and after the international military interventions. In the case of Libya, intervention occurred directly under the R2P principle; in the cases of Syria, Afghanistan and Iraq, similar arguments were used (preventing civilian casualties) even though intervention was not supported by the UN but was conducted unilaterally by the US and/or NATO.

Kenya. The intervention to overthrow former Ivory Coast President Laurent Gbabgo is much more controversial. This occurred shortly after Gbabgo decided to create a Central Bank that would allow the Ivory Coast to have its own currency and free itself from the monetary dependence of other former French colonies in the region, whose currency remains under French control. This initiative is similar to that which Khadaffi attempted shortly before the same principle of intervention was applied against him. Although currently on trial the International Criminal Court for war crimes and crimes against humanity, Gbabgo's removal from power by an opposition force with strong French support is still questioned by many organizations. Debatably, it constitutes another example of the use of the "responsibility to protect" principle as an excuse to violate national sovereignty for economic gain. This is not to deny the human rights violations committed by both Khadaffi and Gbabgo. But these are no different from others that occurred, for example, in Gabon or Equatorial Guinea, which have not evoked the same indignation, denunciations or "interventions." I am grateful to Kerry Whigham for the information on the implementation of R2P principles in the cases of Kenya and Ivory Coast and for pointing out the need to include them. I am also grateful to Cruz Melchor Eya Nchama for the information on Cote D'Ivoire. Critical references to Lybia and Cote D'Ivoire can also be found in Jean Ping, Éclipse sur l'Afrique, Fallait-il tuer Kadhafi? (Paris: Michalon, 2014) and Yash Tandon, Le Commerce, c'est la guerre, (Geneva: Cetim, 2015). 
Figure 1: Victims of Armed Conflict 2007-2016, organized by total number ${ }^{4}$

\begin{tabular}{|lccccccccccc|} 
& 2007 & 2008 & 2009 & 2010 & 2011 & 2012 & 2013 & 2014 & 2015 & 2016 & TOTAL \\
\hline 1) Syria & - & - & - & - & 965 & 38500 & 69086 & 57529 & 46643 & 44303 & 257026 \\
\hline 2) Afghanistan & 6906 & 5552 & 6341 & 6864 & 7405 & 7719 & 8056 & 12285 & 17273 & 17980 & 96381 \\
\hline 3) Iraq & 2217 & 2200 & 1043 & 1144 & 1072 & 638 & 1882 & 12149 & 10138 & 9016 & 41499 \\
\hline 4) Pakistan & 747 & 3537 & 6864 & 6052 & 2863 & 3018 & 1802 & 3136 & 2077 & 761 & 30857 \\
\hline 5) Sri Lanka & 2494 & 8262 & 10165 & - & - & - & - & - & - & - & 20921 \\
\hline 6) Somalia & 1579 & 1529 & 1481 & 2151 & 1937 & 2600 & 896 & 1104 & 1173 & 1925 & 16375 \\
\hline 7) Yemen & - & 21 & 94 & 175 & 1140 & 2330 & 582 & 1660 & 6700 & 2426 & 15128 \\
\hline 8) Nigeria & - & - & 405 & - & 324 & 811 & 1629 & 3811 & 4493 & 2430 & 13903 \\
\hline 9) Sudan & 217 & 620 & 373 & 1054 & 1404 & 1411 & 593 & 849 & 1264 & 1314 & 9099 \\
\hline 10) Congo & 632 & 767 & 1978 & 300 & 283 & 773 & 1531 & 985 & 197 & 261 & 7707 \\
\hline
\end{tabular}

Figure 2: Victims of Armed Conflict 2007-2016, organized by victim/total population rate ${ }^{5}$

\begin{tabular}{|lcccccccccccc|}
\hline & 2007 & 2008 & 2009 & 2010 & 2011 & 2012 & 2013 & 2014 & 2015 & 2016 & Average Rate \\
\hline 1) Syria & - & - & - & - & 0,046 & 1,885 & 3,488 & 2,996 & 2,490 & 2,404 & 2,662 \\
\hline 2) Sri Lanka & 0,126 & 0,414 & 0,506 & - & - & - & - & - & - & - & 0,349 \\
\hline 3) Afghanistan & 0,259 & 0,203 & 0,226 & 0,238 & 0,249 & 0,251 & 0,254 & 0,375 & 0,512 & 0,519 & 0,343 \\
\hline 4) Libya & - & - & - & - & 0,312 & - & - & 0,052 & 0,044 & 0,274 & 0,227 \\
\hline 5) Somalia & 0,143 & 0,134 & 0,126 & 0,178 & 0,156 & 0,204 & 0,068 & 0,082 & 0,084 & 0,134 & 0,146 \\
\hline 6) Iraq & 0,078 & 0,076 & 0,035 & 0,037 & 0,034 & 0,019 & 0,056 & 0,347 & 0,281 & 0,242 & 0,134 \\
\hline 7) South Sudan & - & - & - & - & 0,021 & 0,025 & 0,083 & 0,145 & 0,041 & 0,058 & 0,075 \\
\hline 8) Yemen & - & 0,001 & 0,004 & 0,007 & 0,047 & 0,094 & 0,023 & 0,063 & 0,249 & 0,088 \\
\hline 9) Ukraine & - & - & - & - & - & - & - & 0,097 & 0,029 & 0,006 & 0,0672 \\
\hline 10) Israel & 0,040 & 0,094 & 0,094 & 0,004 & 0,007 & 0,008 & - & 0,210 & - & - & 0,065 \\
\hline
\end{tabular}

${ }^{4}$ Author production. World Bank, “Database International Development," accessed September 22, 2019, http://databank. bancomundial.org/data/source/world-development-indicators/preview/on. Last Updated: 07/25/2018. Indicator Name: Battle-related deaths (number of people). Definition: Battle-related deaths are deaths in battle-related conflicts between warring parties in the conflict dyad (two conflict units that are parties to a conflict). Typically, battle-related deaths occur in warfare involving the armed forces of the warring parties. This includes traditional battlefield fighting, guerrilla activities, and all kinds of bombardments of military units, cities, and villages, etc. The targets are usually the military itself and its installations or state institutions and state representatives, but there is often substantial collateral damage in the form of civilians being killed in crossfire, in indiscriminate bombings, etc. All deaths--military as well as civilian--incurred in such situations, are counted as battle-related deaths. Alternate source: Uppsala Conflict Data Program, http://www.pcr.uu.se/research/ucdp/.

${ }^{5}$ Sources are similar to Figure 1. When information is not available for a given year, the rate is estimated only for the years in which there was reliable information. 
The figures are very clear. But if we widen the focus from casualties in military conflicts to the total number of civilian casualties or violence in a society, including all kinds of violent death, the results are even more striking. Figures 3 and 4 show the top ten countries with the highest Intentional Homicide Rate. Most countries among the top ten are totally excluded from discussions about mass violence (Brazil, Mexico, South Africa, the USA, Colombia, Honduras, El Salvador, and Jamaica). Moreover, the list includes three of the five permanent members of the UN Security Council, the body which selects countries for military intervention. South Africa has played a significant role in the development of transitional justice but is one of the most violent countries in the world. It seems that the "reconciliation" without justice proposed by the South African Truth and Reconciliation Commission is not the recipe South African representatives and many NGOs, journalists and scholars are trying to sell to the international community. Brazil's number one position in total number of deaths could be a fundamental variable for understanding the rise of a new fascism in Brazil and Bolsonaro's victory in the October 2018 presidential election.

Figure 3: Intentional Homicide 2007-2016, organized by total numbers ${ }^{6}$

\begin{tabular}{|lccccccccccc|}
\hline UNODC Name & 2007 & 2008 & 2009 & 2010 & 2011 & 2012 & 2013 & 2014 & 2015 & 2016 & TOTAL \\
\hline 1) Brazil & 44.625 & 45.885 & 44.518 & 43.272 & 48.084 & 53.054 & 54.163 & 57.091 & 58.459 & 61.283 & 510.434 \\
\hline 2) India & 45.362 & 45.999 & 45.824 & 46.460 & 47.640 & 47.478 & 45.878 & 47.356 & 44.385 & 42.678 & 459.060 \\
\hline 3) Mexico & 8.867 & 14.006 & 19.803 & 25.757 & 27.213 & 25.967 & 23.063 & 20.010 & 20.762 & 24.559 & 210.007 \\
\hline 4) South Africa & 18.400 & 18.084 & 16.767 & 15.893 & 15.554 & 16.213 & 17.023 & 17.805 & 18.673 & 19.016 & 173.428 \\
\hline $\begin{array}{l}\text { 5) United States } \\
\text { of America }\end{array}$ & 17.128 & 16.485 & 15.399 & 14.722 & 14.661 & 14.856 & 14.319 & 14.164 & 15.883 & 17.250 & 154.867 \\
\hline 6) Colombia & 17.198 & 16.140 & 15.817 & 15.459 & 16.127 & 16.440 & 15.419 & 13.343 & 12.782 & 12.402 & 151.127 \\
\hline $\begin{array}{l}\text { 7) Russian } \\
\text { Federation }\end{array}$ & 25.377 & 23.738 & 21.371 & - & - & - & 15.763 & 16.260 & 16.519 & 15.561 & 134.589 \\
\hline $\begin{array}{l}\text { 8) Venezuela } \\
\text { (Bolivarian } \\
\text { Republic of) }\end{array}$ & 13.156 & 14.589 & 13.985 & 13.080 & 14.098 & 16.072 & - & 19.030 & - & 17.778 & 121.788 \\
\hline 9) Pakistan & 10.556 & 12.059 & 12.491 & 13.190 & 13.860 & 13.846 & 13.937 & 13.276 & 9.486 & 8.516 & 121.217 \\
\hline 10) China & 16.119 & 14.811 & 14.667 & 13.410 & 12.015 & 11.286 & 10.640 & 10.083 & 9.200 & 8.634 & 120.865 \\
\hline
\end{tabular}

\footnotetext{
${ }^{6}$ United Nations Office on Drugs and Crime, "Intentional homicide victims, counts and rates per 100,000 population," accessed September 22, 2019, https://dataunodc.un.org/crime/intentional-homicide-victims. Definition: "Intentional Homicide" means unlawful death inflicted upon a person with the intent to cause death or serious injury. Russian Federation data provided for 2000-2009 are from the World Health Organization and the data from 2013-2016 are from the Prosecutor-General of the Russian Federation, and include victims of attempted homicide.
} 
Figure 4: Intentional Homicide 2007-2016, organized by rate ${ }^{7}$

\begin{tabular}{|lccccccccccc|}
\hline & 2007 & 2008 & 2009 & 2010 & 2011 & 2012 & 2013 & 2014 & 2015 & 2016 & Average Rate \\
\hline 1) Honduras & 46,5 & 56,6 & 65,7 & 76,1 & 85,1 & 84,3 & 74,3 & 66,9 & 57,5 & 56,5 & 66,94 \\
\hline 2) El Salvador & 57,5 & 52,0 & 71,4 & 64,7 & 70,6 & 41,7 & 40,2 & 62,4 & 105,4 & 82,8 & 64,88 \\
\hline 3) Venezuela & 47,5 & 51,8 & 48,9 & 45,1 & 47,8 & 53,8 & - & 61,9 & - & 56,3 & 51,65 \\
\hline 4) Jamaica & 57,1 & 58,0 & 60,0 & 51,4 & 40,0 & 38,7 & 42,1 & 35,1 & 42,1 & 47,0 & 47,15 \\
\hline 5) Lesotho & 45,1 & 37,6 & 35,8 & 37,4 & 34,5 & 30,7 & 31,1 & - & 41,2 & - & 36,69 \\
\hline 6) Guatemala & 42,2 & 44,9 & 45,4 & 40,7 & 38,0 & 33,8 & 33,7 & 31,4 & 29,4 & 27,3 & 36,67 \\
\hline 7) South Africa & 36,9 & 35,9 & 32,9 & 30,8 & 29,8 & 30,6 & 31,7 & 32,6 & 33,8 & 34,0 & 32,89 \\
\hline 8) Colombia & 38,8 & 35,9 & 34,8 & 33,7 & 34,8 & 35,1 & 32,6 & 27,9 & 26,5 & 25,5 & 32,55 \\
\hline 9) Trinidad and Tobago & 29,9 & 41,6 & 38,4 & 35,6 & 26,4 & 28,3 & 30,3 & 29,9 & 30,9 & - & 32,35 \\
\hline 10) Brazil & 23,4 & 23,8 & 22,8 & 22,0 & 24,2 & 26,5 & 26,8 & 28,0 & 28,4 & 29,5 & 25,52 \\
\hline
\end{tabular}

A third way to calculate civilian casualties in conflicts is by examining the number of refugees. Again, we find the same situation as before: large numbers of refugees do not necessarily trigger military interventions, as is shown in Figure 5 and Figure 6. And where the two coincide, the number of refugees increases after the intervention and not before.

Figure 5: Refugees 2007-2016, organized by average numbers ${ }^{8}$

\begin{tabular}{|lcccccccccccc|} 
& 2007 & 2008 & 2009 & 2010 & 2011 & 2012 & 2013 & 2014 & 2015 & 2016 & Average \\
\hline 1) Afghanistan & 3.057 .661 & 2.833 .128 & 2.887 .123 & 3.054 .709 & 2.664 .436 & 2.586 .152 & 2.556 .502 & 2.596 .270 & 2.666 .305 & 2.501 .445 & 2.740 .373 \\
\hline 2) Syria & 13.690 & 15.211 & 17.914 & 18.452 & 19.931 & 729.022 & 2.468 .332 & 3.887 .491 & 4.873 .243 & 5.524 .377 & 1.756 .766 \\
\hline 3) Iraq & 2.309 .245 & 1.903 .519 & 1.785 .212 & 1.683 .579 & 1.428 .308 & 746.206 & 401.466 & 369.954 & 264.094 & 316.030 & 1.120 .761 \\
\hline 4) Somalia & 457.356 & 561.155 & 678.309 & 770.154 & 1.077 .048 & 1.136 .719 & 1.121 .770 & 1.106 .434 & 1.123 .156 & 1.012 .323 & 904.442 \\
\hline $\begin{array}{l}\text { 5) South } \\
\text { Sudan }\end{array}$ & - & - & - & - & - & 87.009 & 114.470 & 616.211 & 778.718 & 1.436 .719 & 606.625 \\
\hline 6) Sudan & 523.032 & 419.248 & 368.195 & 387.288 & 500.014 & 568.943 & 648.942 & 665.967 & 627.087 & 650.640 & 535.936 \\
\hline 7) Myanmar & 191.313 & 184.413 & 406.669 & 415.670 & 414.626 & 415.371 & 479.606 & 479.006 & 451.805 & 490.289 & 392.877 \\
\hline 8) Colombia & 551.744 & 373.532 & 389.753 & 395.577 & 395.949 & 394.117 & 396.717 & 360.298 & 340.127 & 311.062 & 390.888 \\
\hline 9) Sri Lanka & 134.952 & 137.752 & 145.721 & 141.074 & 136.617 & 132.731 & 123.084 & 122.010 & 121.443 & 117.479 & 131.286 \\
\hline 10) Turkey & 221.939 & 214.378 & 146.387 & 146.794 & 139.779 & 135.372 & 66.575 & 63.892 & 59.558 & 57.925 & 125.260 \\
\hline
\end{tabular}

\footnotetext{
${ }^{7}$ United States Virgin Islands, Saint Kitts and Nevis, Belize, and Bahamas were excluded from the top ten because they have a population fewer than 400.000 inhabitants. United Nations Office on Drugs and Crime, "Intentional Homicide victims, counts, and rates per 100,000 population," accessed September 22, 2019, https://dataunodc.un.org/crime/ intentional-homicide-victims.

${ }^{8}$ United Nations Office of the High Commissioner for Refugees, "Population Statistics Database," accessed September 22, 2019, http://popstats.unhcr.org/en/time series.
} 
Figure 6: Refugees 2007-2016, organized by rate (refugees / total population of the country) ${ }^{9}$

\begin{tabular}{|lcccccccccccc|} 
& 2007 & 2008 & 2009 & 2010 & 2011 & 2012 & 2013 & 2014 & 2015 & 2016 & $\begin{array}{c}\text { Average } \\
\text { Rate }\end{array}$ \\
\hline 1) Syria & 0,70 & 0,75 & 0,86 & 0,88 & 0,96 & 35,70 & 124,61 & 202,44 & 260,11 & 299,74 & 92,67 \\
\hline 2) Afghanistan & 114,88 & 103,80 & 103,10 & 106,05 & 89,69 & 84,25 & 80,57 & 79,26 & 79,03 & 72,18 & 91,28 \\
\hline 3) Somalia & 41,43 & 49,36 & 57,94 & 63,90 & 86,83 & 89,06 & 85,42 & 81,88 & 80,76 & 70,70 & 70,73 \\
\hline $\begin{array}{l}\text { 4) South } \\
\text { Sudan }\end{array}$ & - & - & - & - & - & 8,04 & 10,24 & 53,44 & 65,54 & 117,47 & 42,45 \\
\hline 5) Iraq & 81,34 & 65,39 & 59,72 & 54,73 & 45,02 & 22,77 & 11,85 & 10,57 & 7,31 & 8,49 & 36,72 \\
\hline 6) Sudan & 16,20 & 12,72 & 10,94 & 11,26 & 14,22 & 15,81 & 17,61 & 17,65 & 16,23 & 16,44 & 14,91 \\
\hline 7) Colombia & 12,43 & 8,32 & 8,58 & 8,61 & 8,53 & 8,41 & 8,38 & 7,54 & 7,05 & 6,39 & 8,43 \\
\hline 8) Myanmar & 3,89 & 3,73 & 8,17 & 8,29 & 8,20 & 8,15 & 9,32 & 9,23 & 8,62 & 9,27 & 7,69 \\
\hline 9) Sri Lanka & 6,81 & 6,91 & 7,26 & 6,98 & 6,72 & 6,50 & 6,00 & 5,92 & 5,86 & 5,65 & 6,46 \\
\hline 10) Mali & 0,33 & 0,12 & 0,20 & 0,24 & 0,28 & 9,37 & 9,27 & 8,21 & 8,83 & 8,69 & 4,55 \\
\hline
\end{tabular}

Myanmar, Colombia, Sri Lanka and Turkey are never mentioned in discussions on R2P and military interventions, even if they are among the top ten in one or more of the figures mentioned above.

\section{The Consequences of Military Interventions}

The second main criterion for military intervention under the R2P - that it reduces violence against civilians - has clearly not been met. In fact, the figures show exactly the opposite. Violence has grown to catastrophic levels precisely after such interventions where they were not found to be critical before the interventions on any of the indicators. Some civilian casualties occurred during the interventions themselves but most happened as countries descended into social and political chaos after the interventions. This was the case in Iraq in 2003 although it is true that the intervention was carried out by NATO forces without the authorization of the UN. In fact, the number of civilian casualties in both Iraq and Libya was not very high before the interventions; the threat of victimization was much greater than the reality of destruction. In both countries the number of casualties, intentional homicides, refugees and internally displaced persons increased dramatically after the military interventions.

The first military intervention carried out under the R2P principle was in Libya in March 2011. This is one of the most interesting cases, precisely because it was the first case that "followed the book". Civilian casualties before the intervention have been estimated at between 233 (Human Rights Watch) - the lowest and probably the most reliable figure - and 2,000 (World Health Organization). The Coalition against War Criminals places the number at 519. Nevertheless, even if we accept the highest estimate, Libya did not rank among the top ten for civilian casualties in 2011 (see figures above).

So, a fundamental question would be why the UN decided to intervene in Libya and not in Sri Lanka or Sudan, for example, which had higher numbers of casualties, intentional homicides, refugees and internally displaced persons at the time of the intervention. This question becomes all the more urgent if we consider that the NATO airstrike campaign in Libya in 2011 caused more than 1,100 civilian casualties and the total number of civilian casualties for the whole year was estimated by the Libyan National Transitional Council at around 30,000. Amnesty International estimates around 350,000 internally displaced people from the beginning of the intervention in

${ }^{9}$ Ibid. Total population was taken from United Nations, Department of Economic and Social Affairs, Population Division. 
March 2011 to the end of 2016. The number of victims of armed conflict in 2016 - the last year with certified information - was 1,727, a level similar to the five previous years following the intervention.

In short, it is clear that the military intervention did not guarantee civilian protection under the R2P principle. On the contrary, it clearly did more harm than good, and caused anything between five and thirty times as many civilian casualties as existed before the decision to intervene. Exactly the same thing happened after the NATO military intervention in Iraq in 2003, which was supposed to prevent the use of chemical weapons that never were found.

\section{Other Elements Explaining Military Interventions}

If the main criteria for military intervention are not being met, why do countries continue to insist on them? The most common critical response to this question is that violence against civilians is used as an excuse to occupy regions with oil and gas reserves. This idea seems plausible in view of increasing international confrontations and competition for resources and Figures 7 \& 8 show a clear correlation between major oil and gas reserves and military intervention. Even if correlation is not explanation, at least it gives us a less contradictory possibility than the failed call to "prevent civilian casualties".

Figure 7: International Top Ten Oil Reserves, $2016^{10}$

\begin{tabular}{|l|l|l|}
\hline RANK & COUNTRY & (BBL) \\
\hline $\mathbf{1}$ & VENEZUELA & $300,900,000,000$ \\
\hline $\mathbf{2}$ & SAUDI ARABIA & $266,500,000,000$ \\
\hline $\mathbf{3}$ & CANADA & $169,700,000,000$ \\
\hline $\mathbf{4}$ & IRAN & $158,400,000,000$ \\
\hline $\mathbf{5}$ & IRAQ & $142,500,000,000$ \\
\hline $\mathbf{6}$ & KUWAIT & $101,500,000,000$ \\
\hline $\mathbf{7}$ & UNITED ARAB EMIRATES & $97,800,000,000$ \\
\hline $\mathbf{8}$ & RUSSIA & $80,000,000,000$ \\
\hline $\mathbf{9}$ & LIBYA & $48,360,000,000$ \\
\hline $\mathbf{1 0}$ & NIGERIA & $37,060,000,000$ \\
\hline
\end{tabular}

${ }^{10}$ Definition: Crude oil - proved reserves is the stock of proved reserves of crude oil in barrels (bbl). Proved reserves are those quantities of petroleum which, by analysis of geological and engineering data, can be estimated with a high degree of confidence to be commercially recoverable from a given date forward, from known reservoirs and under current economic conditions. CIA, The World Factbook, accessed September 22, 2019, https://www.cia.gov/library/ publications/the-world-factbook/rankorder/2244rank.html. The data was updated on 01/01/2017. 
Figure 8: International Top Ten Gas Reserves, 2016"1

\begin{tabular}{|c|l|l|}
\hline RANK & COUNTRY & (CU $\mathbf{~}$ ) \\
\hline $\mathbf{1}$ & RUSSIA & $47,800,000,000,000$ \\
\hline $\mathbf{2}$ & IRAN & $33,500,000,000,000$ \\
\hline $\mathbf{3}$ & QATAR & $24,300,000,000,000$ \\
\hline $\mathbf{4}$ & UNITED STATES & $8,714,000,000,000$ \\
\hline $\mathbf{5}$ & SAUDI ARABIA & $8,602,000,000,000$ \\
\hline $\mathbf{6}$ & TURKMENISTAN & $7,504,000,000,000$ \\
\hline $\mathbf{7}$ & UNITED ARAB EMIRATES & $6,091,000,000,000$ \\
\hline $\mathbf{8}$ & VENEZUELA & $5,701,000,000,000$ \\
\hline $\mathbf{9}$ & NIGERIA & $5,284,000,000,000$ \\
\hline $\mathbf{1 0}$ & CHINA & $5,194,000,000,000$ \\
\hline
\end{tabular}

The most striking examples are Venezuela and Iran, where interventions are constantly proposed by different US government statements, mass media and even scholarly works. ${ }^{12}$ Both cases lie far below the top ten in any of the figures cited. The only exception is the homicide rate in Venezuela, which has escalated dramatically over the last few years, but is still lower than Honduras or El Salvador, where no intervention has been requested. Unlike Venezuela, Honduras has a dictatorial government, which came to power after a coup d'état in which hundreds of opposition members and journalists were killed by the security forces. Honduras finally made the news at the end of 2018. A caravan of refugees and migrants from Honduras and Guatemala numbering around five thousand walked across Mexico in an attempt to reach the US border, where President Trump promised to deploy US security forces to stop them.

On the other hand, Venezuela has the largest oil reserves in the world and eighth largest gas reserves. Intervention could guarantee control of these resources as happened previously in Iraq and Libya. Similarly, Iran currently holds the fourth largest oil reserves in the world and second largest gas reserves. This is not to deny Iran's controversial nuclear project but simply to place it within a broader context.

If we look at the top ten countries with energy resources, we can see that their territories are controlled directly by the main superpowers (US, Russia, China). The US controls Saudi Arabia and the Emirates through puppet regimes, while Russia does the same in Turkmenistan and other former Soviet republics. But the superpowers also control resources through military interventions in the name of R2P (Libya) or with other humanitarian excuses (Iraq). At the same time, R2P concerns are clearly ignored in countries with no resources, even if - like Sri Lanka, Honduras or Myanmar - they are in the top ten of civilian casualties or refugees.

\section{The Challenge of Critical Thinking}

The current situation regarding genocide prevention is very worrying. On the one hand, the media attempts to stir up our emotions with images of civilian casualties, whether dozens of people

${ }^{11}$ Definition: Natural gas - proved reserves compares the stock of proved reserves of natural gas in cubic meters (cu m). CIA, The World Factbook, accessed September 22, 2019, www.cia.gov/library/publications/the-world-factbook/ rankorder/2253rank.html. The data was updated on 01/01/2017, with the exception of the USA, with data updated on $1 / 1 / 2016$.

12 "Trump alarms Venezuela with Talk of a Military Option," New York Times, August 12, 2017, accessed November 22, 2019, https://www.nytimes.com/2017/08/12/world/americas/trump-venezuela-military.html. Among many other calls from politicians or journalists in 2017 and 2018, see Simon Tysdall, "Trump is risking more than a war of words with Iran," The Guardian, September 26, 2018, accessed November 22, 2019, https://www.theguardian.com/ commentisfree/2018/sep/26/trump-idiocy-war-iran-president-midterms. There have been numerous other calls for intervention in the last decade from politicians and journalists, in addition to many from scholars. 
have been killed or just a few. No one asks why these images are shown instead of others, why these civilian casualties deserve our attention while other victims (usually more numerous, as we have shown above) are totally ignored. After an intense period of focusing on a particular group of victims, the call starts: we have the duty to intervene. And a chorus of politicians and journalists start voicing their calls: "How long are we going to stand by? We have to stop the violence!! Time for intervention is now!!" Almost no one asks why that particular territory is the focus of the mass media, diplomats or scholars: why Libya and not Honduras, why Iraq, Iran or Venezuela instead of Yemen, Sri Lanka, Myanmar or Mexico. It is left to the victims of Honduras, Yemen or Mexico to voice the call for intervention. But their attempts to gain the attention are nearly always unsuccessful.

Once a country's oil and gas resources are firmly under the control of "peacekeeping" forces, that country quietly disappears from the mass media and political and academic agendas even though, more often than not, the number of casualties continues to grow rapidly. And here is the truly amazing part: no-one stops to evaluate if anything has changed. No one cares about the victims after the intervention, neither the media nor academia. No one talks anymore about postintervention Afghanistan, Iraq or Libya. A new case grabs everyone's attention. Now it is the turn of Venezuela and Iran. It is never the turn of Myanmar, Honduras, Yemen or Mexico. Sudan is also there waiting in the wings and maybe one day... one-day intervention will come.

If that last sentence sounded facetious, it is because the general public (and academia as a part of it) has seemingly been reduced to the role of children asking for their parents to "do something" (where parents would be the P5 members at the UNSC). There is no critical analysis, no checking of information, no attempt to think outside the box. We are lost in a terrible cycle of distortion and manipulation and our main complaint seems to be the one expected from us by the hegemonic media: why are the parents (UNSC) not intervening more in those countries where the mass media wants them to act?

Samantha Power's A Problem from Hell is the best example of this kind of discourse: genocide as the result of our non-intervention. ${ }^{13}$ Strategically ignoring whole regions of the world (the whole of Latin America, the whole of Southeast Asia and Indonesia, among others), Power suggests that the main reason for genocide is a lack of US military intervention. Unlike Power's counter-factual assumptions: "if we had intervened..." this paper has tried to illuminate those counterfactuals with real facts: neither UN nor US military interventions happened in the places with the highest civilian casualties. Neither UN nor US military interventions have reduced civilian casualties but rather have increased them.

Finally, it is worth remembering the number of deaths caused by direct or indirect US interventions in Latin America, many of them resulting in genocide and other mass atrocities. Direct interventions include the failed invasion of Cuba (1959), the invasion of the Dominican Republic (1963), attacks on Nicaragua in alliance with the "contras" (from 1979 to the early 1990s), and the invasion of Grenada (1983) and Panama (1989). Indirect interventions include the instigation and support of coups in Guatemala (1954), Paraguay (1954), Haiti (1957), Brazil (1964), Bolivia (1964, 1971 and 1980), Argentina (1966 and 1976), Uruguay (1973), Chile (1973) and the backing of civilian killings under democratic governments in Honduras, Colombia, Ecuador and Mexico. The final death toll is difficult to estimate due to insufficient research, but direct interventions produced at

\footnotetext{
${ }^{13}$ Samantha Power, A Problem from Hell. America and the Age of Genocide (New York: Basic Books, 2002). Even if Power was originally a journalist, her book was extremely popular and it was quoted in almost all of the production on genocide prevention as it summarizes the main arguments from the majority of scholars who work on the field asking for different ways of using intervention as a tool of genocide prevention. See, for example, two of the most known scholars on the field: Gareth Evans, The Responsibility to Protect. Ending Mass Atrocities Once and for All (Washington, DC: The Brookings Institute, 2008) and Alex J. Bellamy, The Responsibility to Protect: A Defense (New York: Oxford University Press, 2015). More directly on the focus and among hundreds of others on the subject, see also: Micah Zenko, "Saving Lives with Speed: Using Rapidly Deployable Forces for Genocide Prevention," Defense E Security Analysis 20, no. 1 (2004), 3-19, accessed September 22, 2019, doi: 10.1080/1475179042000195474; David Scheffer, "Genocide and Atrocity Crimes," Genocide Studies and Prevention 1, no. 3 (December 2006), 229-250 or Dieter Janssen, "Humanitarian intervention and the Prevention of Genocide," Journal of Genocide Research 10, no. 2 (2008), 289-306, accessed September 22, 2019, doi: 10.1080/14623520802075213.
} 
least 20,000 civilian victims - although the figures for Nicaragua, one of the less studied cases, are clearly underestimated. In contrast, indirect interventions produced over 300,000 victims (without counting Colombia and Mexico, which could double the total number).

\section{Instead of Conclusions, Some Provocations}

Over the last decades, Genocide Studies has entered what postmodernists would call a "comfort zone." With fellowships and support from governments or NGOs, we have developed a very comfortable environment in which the knowledge we produce about genocide prevention is neither critical nor useful. We have become trapped by assumptions we have never checked against reality and many of us have chosen to work inside the circle of those assumptions: genocide and mass violence are horrible acts committed by horrible people; we cannot stand by and do nothing; we have the responsibility to protect civilian populations and that responsibility takes the form, as a last resort, of military intervention.

Often it seems that our main - indeed our only - concern regarding genocide prevention is to analyze why our parents (the UNSC) are not willing to put an end to the "bad guys" who are annoying the "good people." There is a lack of analysis about how cases are chosen, the consequences of intervention; what happens in countries after intervention; or what other variables (like oil and gas resources, among many others) could explain the willingness of some countries to disregard the national sovereignty of others. In the last ten years, no article published in either the Journal of Genocide Research or the Journal of Genocide Studies and Prevention has asked these questions. At both the 2017 IAGS and 2018 INOGS Conferences, more than 15\% of the papers presented dealt with "Genocide Prevention" or "Responsibility to Protect." No paper was presented questioning these notions.

It is time to wake up. We are not children and the UNSC are not our parents. The world is not composed of bad people killing civilians and good people at the UNSC who should be persuaded to intervene. On the contrary, the world is complex and different political actors have different interests. Just as genocide and mass violence have been a very effective technology of power in the past, human rights discourse is now being used to justify neo-colonial interventions and control strategic resources.

As scholars our responsibility is to help, if possible, by calling things by their proper names. The purpose of academic work is to produce and analyze data but - most important - to permanently question our assumptions and "common sense" understandings of the world. Without such critical thinking, Genocide Studies and Prevention will be reduced to a timid voice in the hegemonic chorus.

\section{Bibliography}

Bellamy, Alex J. The Responsibility to Protect. A Defense. New York: Oxford University Press, 2015.

Central Intelligence Agency. The World Factbook. Accessed September 22, 2019. https://www.cia. gov/library/publications/the-world-factbook/rankorder/2244rank.html.

Evans, Gareth. The Responsibility to Protect. Ending Mass Atrocities Once and for All. Washington, DC: The Brookings Institute, 2008.

Feierstein, Daniel. “El Peligro del Redireccionamiento de los Conceptos del Derecho Internacional: Las Naciones Unidas, la Corte Penal Internacional y el nuevo papel de los EE.UU." Revista de Estudios sobre Genocidio. No. 2, 83-97. Buenos Aires: EDUNTREF, 2008.

"The Good, the Bad, and the Invisible: A Critical Look at the MARO Report." Genocide Studies and Prevention 6, no. 1 (2011), 39-44. Accessed September 22, 2019. Doi: 10.1353/ gsp.2011.0107

Jiménez de Asúa, Luis. Tratado de Derecho penal, Tomo II. Buenos Aires: Editorial Losada, 1950.

Ping, Jean. Éclipse sur l'Afrique, Fallait-il tuer Kadhafi? Paris: Michalon, 2014.

Power, Samantha. A Problem from Hell: America and the Age of Genocide. New York: Basic Books, 2002.

International Coalition for the Responsibility to Protect. "Crisis in Kenya." Accessed September 22, 2019. www.responsibility toprotect.org/index.php/crises/crisis-in-kenya.

Tandon, Yash. Le Commerce, c'est la guerre. Geneva: Cetim, 2015. 
United Nations Department of Economic and Social Affairs. "Population Division, Total population by country." 2016.

United Nations Office of the High Commissioner for Refugees. "Population Statistics Database." Accessed September 22, 2019. www.popstats.unhcr.org/en/time series.

United Nations Office on Drugs and Crime. "Intentional homicide victims, counts and rates per 100,000 population." Accessed September 22, 2019. www.dataunodc.un.org/crime/ intentional-homicide-victims.

Waller, James. Confronting Evil: Engaging our Responsibility to Prevent Genocide. New York: Oxford University Press, 2016.

Waxman, Matthew. Intervention to stop Genocide and Mass Atrocities. International Norms and US Policy. New York: Council on Foreign Relations, 2009.

World Bank. "Database International Development." Last Updated July 25, 2018. Accessed September 22, 2019. www.databank.bancomundial.org/data/source/world-developmentindicators/preview/on.

Zolo, Danilo. La justicia de los vencedores. De Nuremberg a Bagdad. Buenos Aires: Edhasa, 2007. 